\title{
ANALISIS KINERJA GURU SMP NEGERI SE- KOTA MAKASSAR
}

\author{
Syarifuddin \\ STIE Nobel Indonesia Makassar (syarifuddin@stienobel-indonesia.ac.id)
}

\begin{abstract}
ABSTRAK
Sebagai Ibukota Propinsi seharusnya Pendidikan di Kota Makassar lebih baik jika disbanding kabupaten/kota lain di Propinsi Sulawesi Selatan tetapi kenyataannya kualitas pendidikan masihjauh dari harapan. Demikian juga hasil Uji Kompetensi Guru, data Dinas PendidikanKota Makassar untuk peserta UKG di Kota Makassar, yakni rata-rata nilai di bawah lima puluh. Bahkan,ada guru yang mendapatkan nilai tiga puluh dari seratus soal dalam naskah ujian.Kondisi tersebut tidak sejalan dengan peran guru yang sangat penting dalam peningkatan kualitas pendidikan.sangat penting meningkatkan kinerja guru se-Kota Makassar dalam upaya meningkatkan kualitas pendidikan. Oleh karena itu rumusan masalah dalam penelitian ini adalah (i) Bagaimanakah kinerja guru-guru SMP Negeri se-Kota Makassar? Tujuan penelitian ini adalah (i) Untuk mengetahui kinerja guru-guru SMP Negeri se-Kota Makassar Hasil penelitian menunjukkan (i) kinerja guru SMP Negeri se-Kota Makassar berkategori baik.
\end{abstract}

Kata Kunci : Kinerja Guru

\section{ABSTRACT}

As the capital of the province, education in the Makassar supposed to be better than other cities in the province of South Sulawesi. In fact, the quality of education is still far from expectation. So was the result of the theacher's competence test. Likewise, teacher competency test result, data on the Department of Education in Makassar to participants of UKG in Makassar is the average value of fewer than 50. In fact, there are teachers who receive 30 from 100 questions in the exam. The condition is not in line with the role of the teacher that is crucial in improving the quality of education. Therefore, it is very important to improve the performance of teachers in all junior high school in Makassar in order to improve the quality of education with the problems of this research consist of (i) how is the performance of the teachers on all State secondary schools in Makassar? This research aims at (i) finding out the teachers' performance on all State secondary schools in Makassar; The results show that (i) the teachers' performance on all State secondary schools in Makassar are on the good category

Keywords : the performance of the teachers

\section{PENDAHULUAN}

\section{Latar Belakang Masalah}

Faktor-faktor yang mempengaruhi kinerja guru, diantaranya tingkat pendidikan guru, supervisi pengajaran, program penataran, iklim yang kondusif, sarana dan prasarana, kondisi fisik dan mental guru, gaya kepemimpinan kepala sekolah, jaminan kesejahteraan, kemampuan manajerial kepala sekolah dan lain-lain (Sabriana, 2010). Dalam upaya meningkatkan mutu pendidikan disekolah, 
kompetensi guru merupakan salah satu faktor yang amat penting.Kompetensi guru,meliputi kompetensi pedagogik, kompetensi personal, kompetensi sosial,dan kompetensi profesional.Upaya untuk meningkatkan kompetensi guru dapat dilakukan melalui optimalisasi peran kepala sekolah sebagai edukator, manajer, administrator, supervisor, leader, pencipta iklim kerja dan wirausahawan (Ahmad, 2008).

Berdasarkan data hasil uji kompetensi 2015 guru, menunjukkan bahwa guru yang mendapat nilai 70 dan diatas nilai 70 akan dinyatakan lulus dan berkompetensi oleh Kemendiknas, antara lain persentase guru pada tingkat SD sebesar 38\%, guru pada tingkat SMP sebesar 37\%, dan guru pada tingkat SMA/SMK sebesar 37\% data tersebut, menunjukkan tingkat penguasaan kompetensi gurudi Indonesia presentasenya masih sangat rendah (Wawan, 2012)..

Menurut Balitbang Diknas (2007), mengemukakan bahwa guru-guru yang layak mengajar pada tahun 2015 di berbagai satuan pendidikan, sebagai berikut pada tingkat SD yang layak mengajar di negeri dengan sebesar $21 \%$ dandi swasta sebesar 29\%, pada tingkat SMP yang layak mengajar di negeri sebesar $54 \%$ dan di swasta sebesar 61\%, pada tingkat SMA yang layak mengajar di negeri sebesar 65\% dan di swasta sebesar 65\%,pada tingkat SMK yang layak mengajar di negeri sebesar $55 \%$ dan di swasta sebesar $58 \%$.

Kota Makassar adalah Kota Metropolitan. Kota Makassar merupakan ibukota dari Propinsi Sulawesi Selatan yang dalam taglinnya cerdaskan anak didik untuk mendukung Kota Makassar menjadi kota dunia yang berlandaskan kearifan lokal dibarengi dengan kemajuan prestasi di bidang pendidikan sebagai kota dunia (Sirajuddin, 2008).Namun, harapan sebagai kota dunia harus di tunjang oleh pendidikan yang handal belum dapat di wujudkan dari beberapa informasi tentang pendidikan di Kota Makassar, seperti hasil uji kompetensi guru-guru Kota Makassar dan terungkap bahwa kompetensi guru di Kota Makassar termasuk sangat rendah. Dari 6268 jumlah peserta yang mengikuti uji kompetensi guru, hanya sebagian kecil yang mendapatkan nilai sesuai standar yang ditetapkan oleh Kementerian Pendidikan dan Kebudayaan, yakni 70 poin.

Berdasarkan data yang diperoleh dari Dinas Pendidikan Kota Makassar, nilai rata-rata dari hasil UKG yang didapatkan peserta UKG di Kota Makassar yakni 
rata-rata dibawah 50, bahkan ada guru yang mendapatkan nilai 30 dari 100 soal dalam naskah ujian (Dinas pendidikan kota Makassar : 2015).

\section{Rumusan Masalah}

Berdasarkan latar belakang di atas dan latar belakang yang telah dikemukakan sebelumnya, rumusan masalah dalam penelitian ini adalah: Bagaimanakah kinerja guru-guru SMP Negeri se-Kota Makassar?

\section{Tujuan Penelitian}

Tujuan dalam penelitian ini adalah :

Untuk mendapatkan gambaran tentang kinerja guru SMP Negeri se-Kota Makassar.

\section{KERANGKA TEORI}

Guru adalah seorang yang digugu dan ditiru karena dipercaya dan diyakini apa yang disampaikannya. Sebagai seorang yang digugu dan ditiru, maka guru memiliki peran yang sangat dominan bagi seorang murid.Para ahli pendidikan di seluruh dunia sepakat bahwa tugas guru ialah mendidik dan mengajar.Dari pernyataan itu jelas, guru haruslah memberikan layanan pendidikan yang bisa mengubah pola pikir siswa dan bisa membuatnya menjadi lebih baik dari sebelumnya. Guru merupakan tulang punggung dalam kegiatan pendidikan terutama yang berkaitan dengan kegiatan proses belajar mengajar.

Tanpa adanya peran guru maka proses belajar mengajar akan terganggu bahkan gagal. Oleh karena itu, dalam manajemen pendidikan peranan guru dan kinerja atau prestasi kerja guru dalam upaya keberhasilan pendidikan selalu ditingkatkan.Mengingat tantangan dunia pendidikan untuk menghasilkan kualitas sumber daya manusia yang mampu bersaing di era global .Kinerja atau prestasi kerja dapat diartikan sebagai pencapaian hasil kerja sesuai dengan aturan dan standar yang berlaku pada masing-masing organisasi dalam hal ini sekolah, maka jabatan guru adalah "profesi”.Profesi yang dimaksud adalah keahliannya dalam bidang pendidikan. Melakukan pekerjaan mendidik orang-orang yang menjadi peserta didiknya.Pekerjaan ini cukup berat dan tidak dapat dilakukan oleh sembarang orang di luar bidangnya.Karena meliputi tiga komponen, yakni mendidik, mengajar dan melatih.Mendidik berarti meneruskan dan mengembangkan nilai-nilai hidup.Mengajar dapat diartikan sebagai upaya meneruskan dan mengembangkan 
ilmu pengetahuan.Sedangkan, melatih adalah mengembangkan keterampilanketerampilan pada peserta didik.

Menurut Pindarta (1999) ciri-ciri profesi sebagai berikut:

1) pilihan jabatan itu didasari oleh motivasi yang kuat dan merupakan panggilan hidup orang bersangkutan,

2) telah memiliki ilmu pengetahuan dan keterampilan khusus yang bersifat dinamis dan berkembang terus,

3) ilmu pengetahuan dan keterampilan khusus tersebut di atas diperoleh melalui studi dalam jangka waktu lama di perguruan tinggi,

4) punya otonomi dalam bertindak ketika melayani klien,

5) mengabdi kepada masyarakat atau berorientasi kepada layanan sosial, bukan untuk mendapatkan keuntungan financial,

6) tidak mengadvertensikan keahliannya untuk mendapatkan klien,

7) menjadi anggota profesi,

8) organisasi profesi tersebut menentukan persyaratan penerimaan para anggota, membina profesi anggota, mengawasi perilaku anggota, memberikan sanksi, dan memperjuangkan kesejahteraan anggota.

Pengembangan profesionalisme guru menekankan kepada penguasaan ilmu pengetahuan atau kemampuan manajemen beserta strategi penerapannya. Menurut Maister (1997),bahwa profesionalisme bukan sekedar memliki pengetahuan, teknologi dan manajemen tetapi memiliki keterampilan tinggi, memiliki tingkah laku yang dipersyaratkan predikat guru yang profesional sebagaimana yang dijelaskan dalam jurnal Educational Leadership dalam Supriadi (1999), mengatakan:

Untuk menjadi profesional, seorang guru dituntut untuk memiliki lima hal, yaitu:

1) guru mempunyai komitmen pada siswa dan proses belajarnya,

2) guru menguasai secara mendalam bahan/mata pelajaran yang diajarkannya serta cara mengajarnya kepada siswa,

3) guru bertanggung jawab memantau hasil belajar siswa melalui berbagai cara evaluasi, 
4) guru mampu berpikir sistematis tentang apa yang dilakukannya dan belajar dari pengalamannya,

5) guru seyogyanya merupakan bagian dari masyarakat belajar dalam lingkungan profesinya.

\section{METODE PENELITIAN}

\section{Jenis dan Lokasi Penelitian}

Penelitian ini adalah penelitian kuantitatif untuk melihat kinerja guru SMP Negeri se-Kota Makassar

\section{PopulasidanSampel}

1. Populasi

Populasi dalam penelitian ini adalah seluruh SMP Negeri yang ada

Kota Makassar dan di bawah bimbingan dan kordinasi Dinas Pendidikan Kota Makassar mulai dari SMP Negeri 1 sampai dengan SMP Negeri 40 diantara 40 SMP Negeri 8 SSN dan 32 sekolah reguler Makassar dan jumlah populasi guru di Makassar adalah kurang lebih 1200 guru.

2. Sampel

Teknik pengampilan sampel menggunakan tehnik two step stratified proportionalrandom sampling yang di ambil secara acak adalah 10-15\% dari populasi (Suharsimi, 1998: 112).

a) Tahap 1. Dari 8 sekolah SSN (Sekolah Standar Nasional) diambil secara acak 2 sekolah SSN, dan 32 sekolah regular (Standar) diambil secara acak10 sekolah regular. Sehingga jumlah sampel sekolah sebanyak 12 SMP Negeri yang ada di Makassar.

b) Tahap 2.Setiap SMP Negeri yang terpilih di pilih secara acak 12 guru yang terdiridari 3 guru Matematika, 3 guru Bahasa Indonesia, guru Bahasa Inggris, dan 3 guru IPA (Equaal Size Sampling).

Sehingga jumlah sampel guru yang mengajar di SSN adalah 3x4=12 guru dan $12 \times 2 \mathrm{SSN}=24$ guru. Di tambah guru yang mengajar pada sekolah standar (regular) adalah $3 \times 4=12$ dan $12 \times 10$ reguler $=120$. Jadi, jumlah seluruh sampel guru adalah 24 SSN dan 120 Standar 24+ 120=144 guru. 
Teknikpengumpulan data yang digunakanadalah

1) Angket

Angket yang dilakukan dalam penelitian ini adalah membuat angket dalam bentuk pertanyaan-pertanyaan sesuai indikator-indikator: Indikatorkinerja guru,

Tujuan angket ini adalah untuk mengukur kinerja guru, Angket (kuesioner) adalah alat pengumpulan data dengan menggunakan pertanyaan tertulis dan jawaban tertulis pula.Pertanyaan tertulis ini diajukan untuk memperoleh data tentang kerja guru

2) Dokumentasi

Pengambilan data melalui teknik dokumentasi data yang dikumpul kan peneliti berupa foto-foto kegiatan penelitian maupun dokumen-dokumen sebagai bukti fisik untuk memperkuat informasi tentang kinerja guru

\section{InstrumenPengumpulan Data}

Instrumen penelitian yang dipergunakan dalam penelitian ini adalah angket, hasil tersebut kemudian di konversi kedalam nilai skalalikert yang terdiri dariangket yang disusuna dalam angket tertutup dengan menggunakan skalalikert dengan rentang nilai 1-5. Kategori pertanyaan ada dua sifat yaitu, sifat positif dan sifat negatif. Sifatpositif dengan jawaban selalu dengan nilai lima, sering dengan nilai empat, kadang- kadang dengan nilaitiga, jarang dengan nilai 2 dan jawaban tidak pernah dengan nilai satu, sedangkan sifat negative dengan rentang nilai sebaliknya 


\section{HASIL PENELITIAN DAN PEMBAHASAN}

\section{Hasil Penelitian}

Tabel 1 Data Guru Sekolah Menengah Pertama (SMP) pada Tahun Pelajaran 2017

\begin{tabular}{lccccc}
\hline & \multicolumn{5}{c}{ Keadaan Guru Mata Pelajaran } \\
\cline { 2 - 5 } Guru Mata Pelajaran & Butuh & Ada & Kurang & Lebih & $\begin{array}{c}\text { Kekurangan Guru } \\
\text { kalau terjadi } \\
\text { Pemerataan }\end{array}$ \\
\hline Pendidikan Agama & 128 & 116 & 14 & 2 & 12 \\
PKn & 121 & 112 & 18 & 9 & 9 \\
Bahasa Indonesia & 219 & 222 & 18 & 21 & Lebih 3 \\
Bahasa Inggris & 143 & 131 & 17 & 5 & 12 \\
Pendidikan Jasmani & 134 & 131 & 7 & 4 & 3 \\
Matematika & 211 & 189 & 22 & 9 & 13 \\
IPA & 196 & 214 & 18 & 3 & 2 \\
IPS & 218 & 242 & 24 & 26 & 37 \\
TIK & 102 & 63 & 40 & 3 & Lebih 7 \\
Pendidikan Seni & 106 & 105 & 1 & 8 & 19 \\
Mulok & 80 & 55 & 25 & 6 & \\
\hline
\end{tabular}

Sumber: Dinas Pendidikan Kota Makassar

Berdasarkan tabel 4. di atas,Kota Makassar kekurangan guru dan tidak ada pemerataan guru diantara 40 SMP Negeri se-Kota Makassar. Ada sekolah yang mata pelajaran tertentu kekurangan guru sementara di sekolah lain mata pelajaran tertentu kelebihan guru pada mata pelajaran yang diujian nasionalkan, sepertiBahasa Indonesia terjadi kekurangan sebanyak 18 guru pada SMPN 1, 2, 8, 9, 11, 12, 13, 16, 20, 21, dan SMPN 2. Sementara kelebihan sebanyak 21 guru Bahasa Indonesia pada SMPN 3, 4,15,18, 23, 24, 26, 27, 29, 30, dan SMPN 40. Bahasa Inggris terjadi kekurangan sebanyak 17 guru pada SMPN 14, 15, 18, 21, 22, 25, 26, 27, 28, 37, dan SMPN 38. Sementara kelebihan sebanyak 5 guru Bahasa Inggris pada SMPN 3, 7, 13, 19, dan SMPN 24.Matematika terjadi kekurangan sebanyak 22 guru pada SMPN 1, 2, 3, 9, 16, 17, 19, 21, 22, 26, dan SMPN 32. Sementara kelebihan sebanyak 9 guru Matematika pada SMPN 7, 11, 13, 18, 24, dan SMPN 29. IPA terjadi kekurangan sebanyak 18 guru pada SMPN 16, dan SMPN 21. Sementara kelebihan sebanyak 3 guru IPA pada SMPN 1, 7, dan SMPN 9. 
Kota Makassar, seperti mata pelajaran Pendidikan Agama sebanyak 12, mata pelajaran PKn sebanyak 9, Bahasa Inggris sebanyak 12, Pendidikan Jasmani sebanyak 3, Matematika sebanyak 13, IPA sebanyak 15, IPS sebanyak 2, Teknologi dan Komunikasi sebanyak 37, Mulok sebanyak 19. Sementara mata pelajaran terjadi kelebihan guru di SMPNegerise-Kota Makassar, seperti mata pelajaran Bahasa Indonesia sebanyak 3, Pendidikan Seni sebanyak 7.

Tabel 2 Distribusi Guru Berdasarkan Tingkat Pendidikan

Tahun Pelajaran 2015.

\begin{tabular}{ccccc}
\hline \multirow{2}{*}{ Kualifikasi Pendidikan } & \multicolumn{2}{c}{ SMP/MTs } & \multirow{2}{*}{ Jumlah } & \multirow{2}{*}{$\%$} \\
\cline { 2 - 3 } & SMP & MTs & & \\
\hline Ijazah<S1 & 976 & 74 & 1050 & 20 \\
S1/D4> & 3904 & 295 & 4199 & 80 \\
\hline Total & 4880 & 368 & 5249 & 100
\end{tabular}

Sumber: Dinas Pendidikan Kota Makassar

Tabel di atas menunjukkan bahwa sebanyak4 199 guru dengan persentase sebesar 80 dari 5249 jumlah seluruh guru jenjang pendidikan SMP/MTs di Kota Makassar telah berkualifikasi S1/D4 dan berkualifikasi S2/S3. Disamping itu, sebanyak 1050 guru dengan persentase sebesar 20 guru masih harus ditingkatkan kualifikasinya menjadi S1/D4 sebagai standar kualifikasi seorang guru sesuai UU No. 14 tahun 2005 tentang Guru dan Dosen.

Tabel 3 Jumlah Guru Menurut Kelayakan Mengajar pada Tahun Pelajaran 2015 di Kota Makassar

\begin{tabular}{rlrrrr}
\hline No & \multicolumn{1}{c}{ Variabel } & \multicolumn{1}{c}{ SD } & \multicolumn{1}{c}{ SMP } & \multicolumn{1}{c}{ SMA } & Dikdasmen \\
\hline 1 & Layak & 3755 & 4199 & 4026 & 11981 \\
2 & Tidak Layak & 991 & 1050 & 516 & 2556 \\
& Jumlah & 4746 & 5249 & 4542 & 14537 \\
1 & Layak (\%) & 79 & 80 & 89 & 82 \\
2 & Tidak Layak (\%) & 21 & 20 & 11 & 18 \\
\hline
\end{tabular}

Sumber: Dinas Pendidikan Kota Makassar 
Berdasarkan data kelayakan mengajar untuk jenjang SMP Negeri, SMP Swasta dan Tsanawiyah yang layak mengajar sebanyak 4199 dengan persentase sebesar 80 sedangkan tidak layak mengajar sebanyak1 050 dengan persentase sebesar 20 dari jumlah keseluruhan sebanyak 5249 yang mengajar di SMP Negeri, SMP Swasta dan Tsanawiyah.

Berdasarkan data tersebut dapat disimpulkan bahwa guru yang layak mengajar jenjang SMP se-Kota Makassar adalah kategorinya baik.

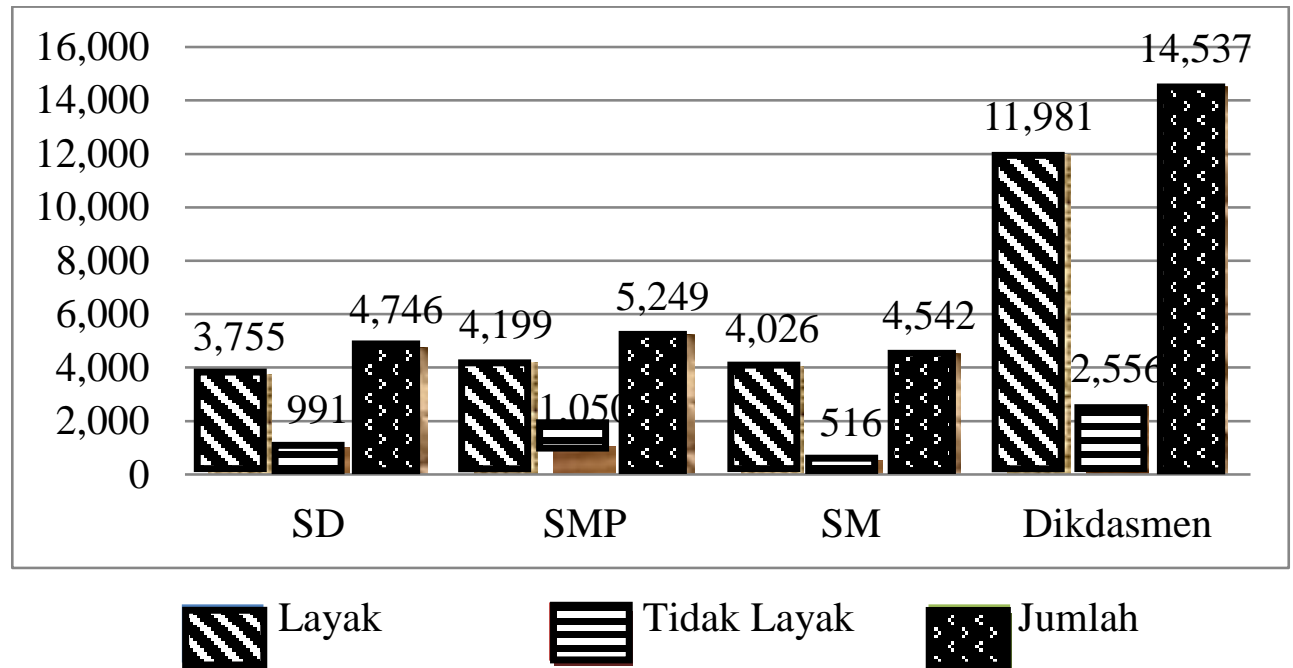

Gambar 4.4 Jumlah Guru Menurut Kelayakan Mengajar pada

Tahun Pelajaran 2015 Sumber: Dinas Pendidikan Kota Makassar 


\section{Data Hasil Perhitungan Statistik}

Perhitungan Persen (\%) Hasil Angket Penelitian kinerja guru

Tabel 4 Hasil Angket Kinerja Guru SMP Negeri Se- Kota Makassar

\begin{tabular}{|c|c|c|c|c|c|c|c|c|c|c|c|c|c|}
\hline \multirow[b]{2}{*}{$\underset{\Xi}{\Xi}$} & \multicolumn{12}{|c|}{ Hasil Angket Kinerja Guru Smp Negeri Kota Makassar } & \multirow[b]{2}{*}{$\sum_{\Sigma}^{E}$} \\
\hline & $\sum_{n}^{n}$ & $\frac{Z}{\sum_{n}}$ & $\frac{\sim}{\sim}$ & $\frac{\Xi}{ \pm}$ & $\sum_{n}^{\infty}$ & $\frac{a}{\sum_{n}^{\infty}}$ & $\sum_{i}^{\stackrel{N}{N}}$ & $\sum_{i=1}^{\curvearrowright}$ & 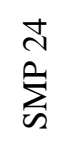 & 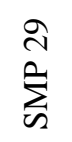 & $\sum_{n}^{n}$ & $\sum_{n}^{\hat{n}}$ & \\
\hline A & 278 & 295 & 269 & 232 & 296 & 264 & 271 & 292 & 279 & 264 & 250 & 282 & \\
\hline $\mathrm{B}$ & 263 & 289 & 285 & 258 & 295 & 252 & 267 & 291 & 251 & 305 & 291 & 291 & \\
\hline $\mathrm{C}$ & 267 & 305 & 204 & 258 & 295 & 279 & 261 & 275 & 240 & 258 & 228 & 292 & \\
\hline $\mathrm{D}$ & 232 & 265 & 271 & 216 & 268 & 277 & 248 & 291 & 243 & 258 & 263 & 266 & \\
\hline $\mathrm{E}$ & 253 & 281 & 248 & 268 & 270 & 232 & 239 & 260 & 276 & 269 & 224 & 284 & \\
\hline $\mathrm{F}$ & 239 & 256 & 267 & 249 & 255 & 270 & 234 & 254 & 263 & 252 & 242 & 274 & \\
\hline $\mathrm{G}$ & 265 & 292 & 279 & 220 & 237 & 287 & 264 & 238 & 286 & 288 & 257 & 266 & \\
\hline $\mathrm{H}$ & 241 & 290 & 264 & 237 & 270 & 253 & 289 & 269 & 279 & 257 & 280 & 287 & \\
\hline I & 273 & 295 & 244 & 232 & 277 & 258 & 225 & 265 & 247 & 233 & 263 & 307 & \\
\hline $\mathbf{J}$ & 253 & 258 & 262 & 274 & 289 & 262 & 261 & 256 & 257 & 284 & 250 & 266 & \\
\hline $\mathrm{K}$ & 254 & 271 & 235 & 264 & 259 & 236 & 226 & 257 & 269 & 281 & 262 & 267 & \\
\hline $\mathrm{L}$ & 259 & 295 & 217 & 229 & 258 & 232 & 225 & 277 & 233 & 281 & 262 & 285 & \\
\hline
\end{tabular}

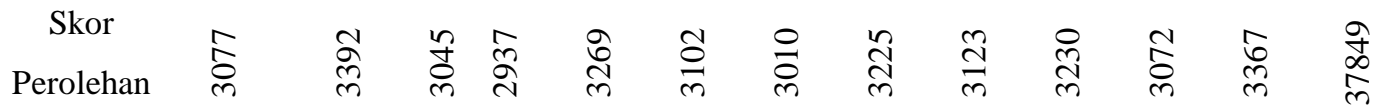

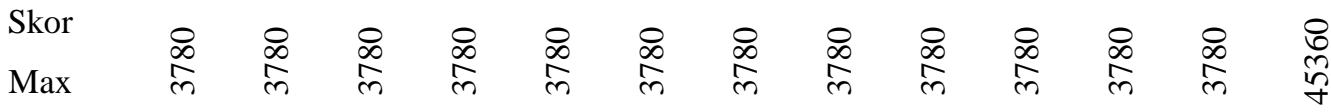

$$
\text { Persentase }=\frac{37849}{45360} \times 100=83 \%(\text { Baik })
$$

Sumber: Hasil Angket Kinerja Guru oleh Guru Mapel Ujian Nasional

Tabel hasil perhitungan persentase hasil angket kinerja guru tingkat SMP Negeri se-Kota Makassar, dimana nilai perolehan hasil angket kinerja guru mata pelajaran yang di UN-kan diperoleh nilai total angket sebesar 37849, sedangkan nilai maksimal yang diperoleh dari nilai tertinggi angket $5 \times 63 \times 12=45360$. Kemudian nilai 
perolehan 37 849x100=3784900.Nilai tersebut dibagi 45360 dan hasilnya sebesar $83 \%$.Berdasarkan hasil perhitungan persentase kinerja guru sebesar $83 \%$, yaitu kategori baik.Sehingga dapat disimpulkan bahwa, kinerja guru tingkat SMP Negeri se- Kota Makassar adalah Baik.

Tabel 5 Rangkuman Data Deskriptif Hasil Angket Penelitian Kinerja Guru,

\begin{tabular}{ccccccccc}
\hline \multirow{2}{*}{ Variabel } & \multicolumn{9}{c}{ Data Deskriptif } & Ket \\
\cline { 2 - 6 } & Mean & Median & Mode & $\begin{array}{c}\text { Std. } \\
\text { Deviation }\end{array}$ & $\begin{array}{l}\text { Nilai } \\
\text { Maximum } \\
\text { Angket }\end{array}$ & $\begin{array}{l}\text { Nilai } \\
\text { Perolehan } \\
\text { Angket }\end{array}$ \\
\hline Kinerja Guru & 262,8 & 264 & 258 & 21,1 & 5360 & 37849 & 83 & Baik
\end{tabular}

\section{Sumber: Hasil SPSS versi 20}

Keterangan:

$$
\begin{array}{ll}
91,0-100 & =\text { Amat Baik } \\
76,0-90,9 & =\text { Baik } \\
61,0-75,9 & =\text { Cukup } \\
51,0-60,9 & =\text { Sedang } \\
& =\text { Kurang }
\end{array}
$$

Kurang Dari 51

Sumber Kemendiknas 2012:35

Tabel 4.5 rangkuman data deskriptif hasil angket penelitian kinerja guru, kinerja kepala sekolah, keterpenuhan sarana prasarana, motivasi kerja guru dan kepuasan kerja guru hasil angket penelitian tingkat SMP negeri se-kota Makassar, Berdasarkan hasil perhitungan SPSS 20 kinerja guru sebesar 83\% kategori baik.

Berdasarkan data tersebut dapat disimpulkan bahwa perlu peningkatan kualitas kinerja guru pembelajaran SMP baik ke Baik sekali Negeri se- kota Makassar. 
Tabel 6 Hasil Perhitungan Analisis SEM Koefisien Jalur Kinerja Guru

\begin{tabular}{rrrrrrrr}
\hline & & & Estimate & S.E. & C.R. & P & Keterangan \\
\hline$Y_{1}$ & $<--$ & $Y$ & 1,000 & & & & \\
$Y_{2}$ & $<---$ & $Y$ & 0,754 & 0,136 & 5534 & $<0,001$ & Signifikan \\
$Y_{3}$ & $<---$ & $Y$ & 0,664 & 0,112 & 5938 & $<0,001$ & Signifikan \\
\hline
\end{tabular}

Sumber: Hasil Analisis SEM

Kesahihan Konstruk kinerja guru (Y)

1) Kinerja guru terhadap perencanaan pembelajaran SMP Negeri se-Kota Makassar.

$\mathrm{Y} \longrightarrow \mathrm{Y}_{1} \quad$ Signifikan $(\mathrm{p}<0,001)$

Kinerja guru berpengaruh signifikan terhadap perencanaan pembelajaran SMP Negeri se-Kota Makassar.

2) Kinerja guru terhadap pelaksanaan pembelajaran SMP Negeri se-Kota Makassar.

$\mathrm{Y} \longrightarrow \mathrm{Y}_{2} \quad$ Signifikan $(\mathrm{p}<0,001)$

Kinerja guru berpengaruh signifikan terhadap pelaksanaan pembelajaran SMP Negeri se-Kota Makassar.

3) Kinerja guru terhadap evaluasi/penilaian tindak lanjut penilaian SMP Negeri se-Kota Makassar.

$$
\mathrm{Y} \longrightarrow \mathrm{Y}_{3} \quad \text { Signifikan }(\mathrm{p}<0,001)
$$

Kinerja guru berpengaruh signifikan terhadap evaluasi/penilaian tindak lanjut penilaian SMP Negeri se-Kota Makassar.

\section{Pembahasan}

Peningkatan mutu pembelajaran di ukur dengan berbagai indicator, yaitu persentase lulusan, angka kelayakan guru mengajar, persentase kondisi ruang kelas, persentase fasilitas sekolah, angka partisipasi dari biaya, dan satuan biaya sekolah 
khusus untuk SMP dan SMA ditambah dengan indikator kesesuaian guru mengajar menurut bidang studi (Profil dinas pendidikan Makassar 2015).

Kelayakan guru mengajar. Untuk jenjang SMP Negeri, Swasta, dan Tsanawiyah yang layak mengajar sebesar 4199 dengan persentase mencapai $80 \%$ dan tidak layak mengajar sebesar 1050 dengan persentase mencapai $20 \%$ dari 5 249 seluruh jumlah guru. Data tersebut, menunjukkan guru jenjang SMP di Kota Makassar termasuk kategori baik.

Data penelitian hasil angket dan perhitungan kinerja guru SMP Negeri seKota Makassar sebesar 83\%, termasuk kategori baik.

\section{SIMPULAN DAN SARAN}

\section{Kesimpulan}

Berdasar kan hasil penelitian dan pembahasan kesimpulan dalam penelitian ini adalah : Kinerja guru SMPNegeri se-Kota Makassar berkategori baik.

\section{Saran}

Berdasarkan hasil penelitian di sarankan kepada: Pemerintah Kota Makassar melalui Dinas Pendidikan Kota Makassar meningkatkan kinerja Guru SMP Negeri se-Kota Makassar dari kategori baik menjadi baik sekali. Karena kinerja guru melalui hasil UN belum menunjukkan hasil yang menggembirakan dan guru merupakan ujungtombak pendidikan.

\section{DAFTAR PUSTAKA}

Ahmadi, A \&Supriyono, W. 2004.PsikologiBelajar (EdisiRevisi). Jakarta: RinekaCipta.

Aunurrahman. 2009. BelajardanPembelajaran. Bandung: Alfabeta.

Bafadal, Ibrahim. 2008. Peningkatan Profesional Guru Sekolah Dasar. Jakarta: PT Bumi Aksara, h. 5.

Daruma, AR., Sulaiman, S. \& Mustafa. 2009. Perkembangan Peserta Didik. Makassar: FIP UNM

Depdiknas, 2003. Undang-undang RI No.20 Tahun 2003 Tentang Sistem Pendidikan Nasional. 
Depdiknas, 2008. Penilaian Kinerja Guru. Direktorat Tenaga Kependidikan Peningkatan Mutu Pendidik dan Tenaga Kependidikan Depdiknas.

Depdiknas, 2009.Pembangunan Pendidikan SMP. Direktorakrat Jenderal Manajemen Pendidikan Dasar dan Menengah. Jakarta.

Dimyati, Mudjiono. 2006.Belajar dan Pembelajaran. Jakarta: PT. RinekaCipta.

Djamarah, S.B. 1994. Prestasi Belajar dan Kompetensi Guru Surabaya: Usaha Nasional.

Imron, 1995.Pembinaan Guru di Indonesia. Jakarta: PT. DuniaPustaka Jaya.

Sutadipura, 1994.Kompetensi Guru dan Kesehatan Mental. Bandung: PenerbitAngkasa.

Syamsul Bahri, 2011 Faktor yang mempengaruhi Kinerja Guru SD di dataranTinggiMoncongKab.GowaJournal Medtek,Volume 3 Nomor 2 FakultasTehnik: UNM. 